\title{
IgT AND IgD FROM SEA BASS (DICENTRARCHUS LABRAX): LOCALIZATION OF EXPRESSING AND IMMUNOREACTIVE CELLS IN LYMPHOID TISSUES.
}

\author{
Simona Picchietti*, Francesco Buonocore*, Noelia Nuñez Ortiz*, Valentina Stocchi*, Laura \\ Guerra, Elisa Randelli, Giuseppe Scapigliati ${ }^{\S}$
}

University of Tuscia, Dept. DIBAF, 01100 Viterbo, Italy.

\begin{abstract}
To investigate mucosal immunity, from a whole transcriptome of sea bass gills we identified and successively cloned complete cDNA sequences of $\operatorname{IgT}$ and $\operatorname{IgD}$ heavy chains. These sequences have been employed to prepare riboprobes for ISH, and to identify conserved regions of sea bass IgT/IgD in order to select sequences from which synthetic peptides have been prepared. The peptides have been used as immunogens in rabbits to obtain antisera against IgT (RaIgT1) and IgD (RaIgD1) and by employing either riboprobes and antisera, the pattern of $\operatorname{IgT} / \operatorname{IgD}$ expressing tissues and the presence of $\operatorname{IgT} / \operatorname{IgD}$ immunoreactive cells has been investigated. The results by qPCR showed that the IgT gene is mainly expressed in muscle, intestine and gills, and the IgD gene in head kidney. By ISH, the presence of IgT-expressing cells has been detected in the intestine, with their number increasing toward the posterior segment, and in the gills. These data have been confirmed by IHC employing the rabbit antiserum RaIgT1, and extended by revealing the presence of IgTimmunoreactive cells in head kidney and spleen, as well as intense reactivity in intestinal mucus. As expected, in mucosal tissues IgT-immunoreactive cells outnumbered IgM-immunoreactive cells. By IIF and flow cytometry with RaIgT1 we determined the number of IgT-positive cells in organs and tissues, being around $32 \pm 12 \%$ in head kidney leukocytes, $14 \pm 6 \%$ in GIALT and $23 \pm 10 \%$ in spleen leukocytes. At the microscope the IIF-positive cells had the morphology of lymphocytes. By western blotting of head kidney lysates, RaIgT1 stained a $180 \mathrm{kDa}$ band in non-reducing gels and a $74 \mathrm{kDa}$ band in reducing gels and, in addition, RaIgT1 showed cross-reaction with partially purified rainbow trout IgT. Leukocytes from the head kidney were enriched in RaIgT1-positive cells by magnetic sorting, and PCR analysis showed an enrichment of IgT and depletion of IgM expression, respectively, in RaIgT1-enriched cells. These data suggest we obtained an antibody against IgT cells of sea bass.

Preliminary data employing the RaIgD1 showed by IHC the presence of immunoreactive cells in gills, spleen, head kidney, intestine, and work is in progress to highlights the characteristics of sea bass IgD expressing cells.
\end{abstract}

Acknowledgements. The work was financially supported by EU-6FP project Targetfish, n³11993.

\section{KEY WORDS}

Sea bass, Lymphocytes, IgT, IgD, Mucosal immunity.

*These authors contributed equally to this work.

${ }^{\S}$ Corresponding author. Email: scapigg@ unitus.it, Ph./Fax +390761357029 